\title{
Is Socialism A Utopian Dream?
}

\author{
Bruno Jossa \\ University "Federico II" of Naples.
}

doi: 10.19044/esj.2016.v12n8p121 URL:http://dx.doi.org/10.19044/esj.2016.v12n8p121

\begin{abstract}
The idea that the establishment of a centrally planned system or the creation of a worker-controlled system amount to a socialist revolution is closely associated with the main contradictions that Marx highlighted in capitalism: the capital-labour conflict or the mismatch between planned production and anarchical distribution. Analysing these alternative forms of revolution, the author raises a number of questions: which of them fits human nature better? which of them is more closely associated with Darwinian evolutionism? is it correct to assume that democratic firm management tends to improve human nature?
\end{abstract}

Keywords: Socialism, producer cooperatives, Marxism

\section{Introduction}

The claim that socialism can not only be implemented as a democratically managed planned economy, but also as a system of producer cooperatives is denied by orthodox Marxists who do not accept the equation of socialism with democratic firm control. On closer analysis, however, it is grounded in Marx's own works.

Indeed, Marx once wrote: "If cooperative production is not to remain a sham and a snare; if it is to supersede the capitalist system; if the united co-operative societies are to regulate national production upon a common plan, thus taking it under their control, and putting an end to the constant anarchy and periodical convulsions which are the fatality of Capitalist production - what else, gentlemen, would it be but Communism, 'possible' Communism?” (Marx 1871, p. 335).

All the same - let this be repeated - most Marxists strongly doubt that Marx ever thought of a system of producer cooperatives as a new mode of production capable of taking the place of capitalism (see, inter alia, P. Marcuse 2015).

In point of fact, the idea of two alternative models of socialism is closely associated with the two main contradictions that Marx pointed up in capitalism: the capital-labour conflict and the mismatch between planned 
production and anarchical distribution. Anyone emphasising the latter contradiction will think of socialism as a centrally planned economy, while those prioritising the capital-labour conflict will argue that socialism arises when the functions of the 'primary factors of production' are reversed upon the establishment a system of producer cooperatives of the LMF type (see Jossa 2010, pp. 262-63 and Jossa 2011). ${ }^{2526}$

The terms of the problem can be stated by raising a number of questions:

which of the above-mentioned forms of revolution fits human nature better?

which of them is more closely associated with Darwinian evolutionism?

is it correct to assume that democratic firm management tends to improve human nature?

The first question will be answered in the light of the recent biological theory that "genes are selfish"; the assumption for answering the second is, quite obviously, an analysis of Social Darwinism; the third question will just be touched upon since the relevant point was analysed in greater depth elsewhere (see Jossa 2014, chap. IX).

Accordingly, Section 2 provides a cursory outline of the modern biological theory of selfish genes; Section 3 examines Marx's and Engels's views concerning human nature; Section 4 analyses human nature from the perspective of the materialist conception of history; Section 5 offers a short analysis of Social Darwinism; Section 6 analyses the two suggested forms of socialism in order to establish which of them is in line with the assumption that human nature is shaped by selfish genes; Sections 7 draws the conclusions.

\section{The selfish gene}

The biological theory that the actions of living beings are governed by selfish genes is well expounded in a book by Dawkins (1989) which raises the following questions: a) where altruism originates; and b) whether or not human beings are exceptions to the biological rule.

"We are survival machines - Dawkins writes (op. cit., p. vii) - robot

\footnotetext{
25 Although many of Marx's writings bear witness to his concern with producer cooperatives, several commentators have argued that the relevant works are just descriptive in nature and do not reveal Marx's overall evaluation of the real potential of cooperation (see (Lowit 1962, p. 79; see, also, Jossa 2005).

${ }^{26}$ The belief that there are two types of socialist revolution conflicts with the following saying by Bernstein (1901, p. 234): "I am singularly uninterested in understanding what people commonly mean by 'the final goal of socialism'. This goal, whatever it may be, means nothing to me; it is the movement itself which is everything."
} 
vehicles blindly programmed to preserve the selfish molecules known as genes. On being first made explicit in the nineteen-sixties - he argues - this idea appeared revolutionary, but today it has gained wide acceptance within the scientific community. Though originally deriving from Darwinism - he continues - it is expressed in a way which is not Darwin's since rather than focus on the individual organism, it takes a gene's eye view of nature.” Darwin's theory of evolution, which today is nowhere called into question, explains why living beings exist and how they act; but, although great biologists such as Lorenz and Eibl-Eibesfeldt did tread in the wake of Darwin, they had as yet not fully realised how evolution works in actual fact. Only recently, major breakthroughs in biological research have highlighted the unitary nature of all living beings at microscope level (see Di Siena 1972, p. 244). In general terms, it is selfish genes that are responsible for the egoistic behaviour of individuals, but selfishness is a connotation of the gene, rather than the individual. It may come as a surprise that elementary chemical processes and all such within-body interactions as spark off the development and growth of all living beings, including humans, basically involve proteins, but this is what contemporary biology has taught (ibid.).

Nonetheless, there are circumstances under which the selfishness of a gene may foster a limited form of altruism in individual animals. Dawkins defines selfishness and altruism in behavioural, rather than subjective terms. An altruistic man, he argues, is one who helps others at the expense of his own well-being, but actions perceived as altruistic are often nothing but gestures of dissimulated selfishness. A typical case is the individual who will help others only on condition that he will receive something in return.

In Dawkins's view, both the assumption that the instinct for survival connotes the species and the theory of 'group selection' that biologists long assumed to be true are actually misconceptions. It is not species, but genes, that engage in the Darwinian struggle for existence, and it is not true that the individual must be sacrificed for the sake of the superior interest of the species. Evolution is blind to the future: if only the genes had the gift of foresight - he adds (p. 10) - they could see that their best interests lie in restraining their selfish greed in order to prevent the extinction of their species.

Not always, however - Dawkins clarifies - are we obliged to obey our selfish genes; but where we should observe genuinely altruistic human behaviour, we would be "faced with something puzzling, something that needs explaining” (p. 6): “among animals, man is uniquely dominated by culture, by influences learned and handed down, and to understand altruism we have to understand the relation between nature and culture.”

Evolution is not only biological, but also cultural. The gene is not the 
only basis of our ideas on evolution. What is unusual about man - Dawkins argues - can be summed up in a single word: 'culture' (p. 198). Although cultural transmission is not unique to man, it does carry far greater importance for the human species. In short, the role that altruism plays in human behaviour is closely intertwined with culture - in the broadest possible meaning of this word. ${ }^{27}$

In line with the above reflections, Dawkins concludes with the following statement: "if you wish to build a society in which individuals cooperate towards a common good, you can expect little help from biological nature. Let us try to teach generosity and altruism, because we are born selfish” (p. 5). ${ }^{28}$

\section{Marx and Engels on human nature}

Before we attempt an assessment of Dawkins's approach it is worth examining Marx’s view of human nature.

As is well known, Marx's $6^{\text {th }}$ Thesis on Feuerbach (which dates from 1845) states that the human essence is not something given, but it changes when the social relations change. ${ }^{29}$ The English version of Marx's $6^{\text {th }}$ thesis on Feuerbach runs as follows: "Feuerbach resolves the religious essence into the human essence. But the human essence is no abstraction inherent in each individual. In its reality it is the ensemble of the social relations" (see Marx 1845, p. 7). ${ }^{30}$

The anthropological conception of man is also criticised in a later

\footnotetext{
${ }^{27}$ Rawls (2000, p. 158) has pointed out that Kant, unlike Hume, held that any attempt at identifying this principle "does not proceed as part of a lager science of human nature, but begins analytically by elucidating the underlying principle(s) implicit in our commonsense judgments of moral worth."

${ }^{28}$ Gobetti wrote (1924, p. 145): "Human actions are not always governed by logic; indeed, explanations which emphasise the role of rationality are as inadequate as those that prioritise the role of instincts."

${ }^{29}$ Concerning Marx's conception of man and, specifically, his reflections on man in the Theses on Feuerbach, see Mondolfo 1909; Mondolfo 1962, pp. 312 ff.; Fromm 1961; Markus 1966 and a collection of papers by Schaff and Sève (see Schaff \& Sève 1975).

${ }^{30}$ Schaff (1971) warns that this version of Marx's text is wrong although it features in quite a lot of French, Italian, Polish, Russian and other translations. The correct translation, he argues, which does appear in a few French and Italian versions (see Marx 1845, pp. 77 ff.), is not "the essence of man (das menschliche Wesen) is, in its reality, the ensemble of social relationships", but 'the individual (i.e. the non-abstract 'man') is, in his reality, the ensemble of the social relationships. And while it is true that this version somewhat bends the letter of Marx's text, it is fully consistent with Marx's thought. As argued by Althusser (1965a, pp. 218-19), "if we take this phrase literally ... it means nothing at all” because there is no such thing as a 'human essence', an abstract human being, and in order to trace a real, non-abstract man we have to turn to society."

For a more exhaustive analysis of Marx's view of the essence of man, see Althusser 1965a, pp. 202-06, the Preface to Althusser 1965b and Sève 2004, pp.111-36.
} 
work, The German Ideology, where Marx and Engels find fault with the tendency of philosophers to conceive of individuals no longer as subject to the division of labour, but as an ideal under the name of 'Man', "so that at every historical stage 'Man' was substituted for the individuals and shown as the driving force of history" (Marx and Engels 1845-46, p. 65). And in the much praised 'Preface' to A Contribution to the Critique of Political Economy, dated 1859, Marx spelt out in bold letters: "The mode of production of material life conditions the general process of social, political and intellectual life. It is not the consciousness of men that determines their existence, but their social existence that determines their consciousness" ${ }^{31}$ In Marxist terms, therefore, as people living in a capitalistic society tend to develop values and modes of being which depart from those prevailing in non-capitalistic contexts, to understand the real nature of human beings we have to focus on social relations of production.

In Marx's words, "society is the complete unity of man with nature, ... the consistent naturalism of man and the consistent humanism of nature", and "just as society itself produces man so is society produced by him" (Marx 1844, p. 113). Analysing Marx’s approach to this issue in a fine book, written in 1948, Cornu claimed that the common thread running through modern philosophical thought is the grand issue of man's integration into nature and society.

According to Marx, man's basic unity with nature entails that nature undergoes continual changes as a result of human productive activity, that human beings realise themselves as they act upon nature and that the ambit affected by human action includes both the natural environment and the production system in which people operate. As pointed out by Cornu (1955, p. 455), Feuerbach, too, held that the essence of man is realised in his relations with the environment, but unlike Marx he thought of the natural, rather than social environment.

Although Marx rated the influence of the production context as more pervading than that of the natural environment, he, too, spelt out that the actions of human beings were influenced by nature. This is why he wrote (Marx 1844, pp. 122) that "history itself is a real part of natural history - of nature developing into man", and then clarifies (op. cit., pp. 122-23): "sense-perception (see Feuerbach) must be the basis of all science. Only when it proceeds from sense-perception - in the two-fold form of sensuous consciousness and sensuous need - is it true science. History itself is a real

\footnotetext{
${ }^{31}$ See Marx 1859, p. 5. Nonetheless, it is worth considering that Marx also wrote: "The materialist doctrine concerning the changing of circumstances and upbringing forgets that circumstances are changed by men and that it is essential to educate the educator himself. This doctrine must, therefore, divide society into two parts, one of which is superior to society" (see Marx 1845, p. 3).
} 
part of natural history - of nature developing into man. ... The social reality of nature, and human natural science, or the natural science of man, are identical terms” (Marx 1844, p. 137).

This begs the question if modern science - specifically the gene selfishness theory - is at odds with the belief (held both by Marx and Aristotle) that men and women are social beings because they are shaped by production relations, by the environment in which they live and by the interrelations they establish during their lives. From the perspective of Dawkins, inasmuch as it is true that such a contrast exists, it is easily solved because the awareness that selfishness is a connotation of genes, not individuals, makes it possible to assume that human nature, though influenced by gene selfishness, is likely to be principally shaped by the prevailing mode of production and by the environment - two influences that make for sociability and concern with one's fellow-beings.

\section{More on human nature in different economic systems from the perspective of the materialist conception of history}

In Marx's approach, a mode of production is a form of society in which one prevailing production model, conceived of as a compound of productive forces and production relations, confers significance on the system as a whole (see Luporini 1966, p. 170). This is how Engels underscores the importance of this notion in his review of A Contribution to the Critique of Political Economy: "The proposition that 'the process of social, political and intellectual life is altogether necessitated by the mode of production of material life' ... was a revolutionary discovery not only for economics but also for all historical sciences - and all branches of science which are not natural sciences are historical sciences” (see Marx 1859, p. 203). ${ }^{32}$ Similarly, Althusser remarked that Marx's theorisation of modes of production and the way they arise, grow and die away is a formidable contribution to scientific knowledge. By virtue of this discovery, he added, Marx laid the foundations of a theory which is the true underpinning of all the sciences relevant to the 'continent of history', not only of history, sociology, human geography, economics, demographics, but also of psychology, 'social psychology', the disciplines generally known as 'social sciences' and, still more generally, all the 'human sciences' (see Althusser 1969 and 1995, p. 23; see, also, Althusser 1972, pp. 50-51). According to Althusser, therefore, the notion of modes of production becomes central to historical materialism and, consequently, of Marxism as a whole (see

\footnotetext{
${ }^{32}$ From Orfeo 1970 (p. 271) we learn that Antonio Labriola described the materialistic conception of history as "an effective means of splitting the huge and extremely complex working mechanism of society into its simplest constituent parts".
} 
Therborn 1971, p. 104). ${ }^{33}$

In other words, in Marx's view it is only by monitoring the production relations in which human beings act out their respective roles that we can have a correct appreciation of their essence. And the reason is, men only exist thanks to these relations (Karsz 1974, p. 187).

While Marx's stance is probably too radical to be shared, one need not be a Marxist or an advocate of the materialist conception of history to accept the idea that character and psyche are strongly influenced by the relations of production. In the opinion of Fromm (1962, p. 38), the assumption that something as a human nature or the essence of man should actually exist has long been a discredited theory and Karsz, for his part (1974, p. 176), has argued that any attempt at grasping what is termed the 'universal human spirit' entails postulating the most idealistic of categories: human nature. Rawls, too, holds that economic and political institutions determine in part both the sort of persons we want to be and the sort of persons we actually are (Rawls 1971, p. 229). ${ }^{34}$

The influence of institutions on character would seem to justify the argument that one of the main defects of capitalism is its adverse impact on human nature.

With reference to historical materialism, a specialist in psychology reports that the findings of numerous surveys confirm that in capitalism selfishness and greed are specific to a higher social standing. More often than not, the members of the upper classes are seen to be less generous, less altruistic and also less cooperative than lower-class people (see Piff et al. 2012); they are more likely to engage in unethical behaviour, tend to donate a smaller portion of their income to charity and are more likely to cheat. In other words, what is known as 'the bourgeois mentality' is typical of the upper middle class, rather than other classes of society.

The importance that upper class individuals attach to their position in society indicates that social class reshuffling may lead to changes in attitudes and that more collaborative attitudes are likely to develop in a cooperative system (see Ratner 2013).

As argued by Bataille, "the factory only knows of forces that may serve its purposes, proletarians, middlemen, accountants or technicians, but

\footnotetext{
${ }^{33}$ Bloom (1943, p. 5) holds that the notion of society as shaped by its production methods is the climax of Marx's doctrine and Althusser, for his part, emphasised that Marx's theorisation of modes of production marked an epistemological break with the traditional approach to the philosophy of history (see Althusser 1965a, p. 217l). For the evolution of the concept of Marxism, see Haupt 1978, pp. 115-45.

${ }^{34}$ Authors endorsing this view include Donnaruma and Partyka (2012, p. 50), who stress the significant part that economic structures play in shaping the lives and conditions of people in society (Donnaruma \& Partyka 2012, p. 50).
} 
ignores the individual whenever possible. Those caught up in the wheels of this system know nothing of meaningful interpersonal communication: a firm is driven on by flameless greed, it employs labour without heart and worships its own growth as the only divinity” (Bataille 1996, p. 64). More recently, the economist F. H. Hahn has highlighted a stark contrast between the innermost driving force of capitalism and generally recognised ethical values. The Jewish-Christian ethic, he argues, extols virtues such as benevolence and care for our fellow-beings, condemns greed and discourages the accumulation of treasures within this world. In line with this moral code, there is nothing to be admired in individuals who pursue their personal profit rather than sticking to their duties or taking care of their fellow-beings - i.e. in individuals who adopt exactly that kind of behaviour that is expected of people operating in a capitalistic system (see Hahn 1993a, p. 10). ${ }^{35}$

This is the rationale behind my claim that in worker-controlled systems - compared to capitalism - greed would lose clout and benevolence and concern for others would become prominent. ${ }^{36}$ Self-management socialism is a system in which firms are run by workers who compete in markets, and there is general agreement, today, that the primary behavioural principle shaping economic activity in these firms is the aim to maximise the average income of all those working in them. It is not until 1958 that this principle (with which cooperation theorists are likely to have long been familiar) was consistently theorised by Ward. On closer analysis, however, far from constituting a newly-discovered behavioural principle supplementing selfish individualism and ethical motivation, the two general principles governing the actions of humans, the principle dictating the maximisation of per-capita incomes is nothing but the application of the utility principle to cooperation economics. In Keynes's definition (see Keynes 1979, p. 66), self- management is an economic system in which the factors of production are remunerated by dividing the actual product of their joint input into prefixed pro-rata shares; and inasmuch as this is true, workers who strive to maximise individual utility in self-managed firms act rationally if they work towards maximising the aggregate income of the firm, because in this way they will maximise both their own and the other

\footnotetext{
${ }^{35}$ An additional major point that will not be entered upon in this paper is Herbert Marcuse's claim that solidarity, though grounded in instinct, is stifled in a society which is based on classes and that the precondition for a climate of solidarity is consequently the suppression of class divisions - a goal that would be attained in a worker- controlled firm system (see Marcuse 1969, p. 22).

${ }^{36}$ Gustafsson also has recently emphasised that one of the salient characteristics of capitalism is to prioritise corrective motives and actions, rather than an impulse to cooperation (see Gustafsson 1993, p. XVI).
} 
members' shares in the residual of the firm.

In other words, although the per-capita income maximisation principle is consistent with the idea that people pursue their personal profit (and unrelated to the thesis that man is by nature altruistic), it acquires the connotations of a solidarity principle by virtue of the fact that within the framework of the specific nature and organisational criteria of cooperative firms it determines that the members striving to increase their own income will, by the same token, boost the incomes of their fellow-members. As a result, there are reasons for arguing that a cooperative firm system tends to breed feelings of solidarity that may counteract selfish drives in man.

\section{A short analysis of Social Darwinism}

At the beginning I raised the question if Marx's approach was consistent with Darwinism. Before this question is answered, it is necessary to establish whether we are to think of the Darwinian idea of evolution in nature or of Social Darwinism.

Although the claim that Darwin's evolutionary theory can be extended to economics is now shared by a wealth of evolutionary theorists, including Veblen (see, inter alia, Hamilton, 1999, pp. 25-28 and Hodgson 2003), I feel that the idea of a cumulative causation process assumed to be constantly at work in social life (the specific methodological point of Darwinism that Veblen tends to emphasise) should not be accepted without prior in-depth scrutiny. Modern-day science, Veblen wrote (1964, p. 21), theorises a process where causes and effects, far from being observed separately in their own right, are, as it were, the links of a chain formed of a continuous sequence of cumulative changes. In all branches of science - he specified (1964, p. 40) - research is invariably conducted as a process or active sequence, in terms that each finding becomes the starting point for the next step, in a cumulative sequence. In this connection, several institutionalists are said to use cumulative processes in their analyses (among authors holding this view, see Miller 2003, pp. 54-55 and Hodgson 2003, pp. 87-90).

In point of fact, in economic theory a less rigorous cumulative causation process than Myrdal's or Kaldor's is envisaged as a possibility, but not as a general rule. The core idea behind economic theory is that economic processes tend to move towards stability - the exact opposite of the notion underlying cumulative causation; ${ }^{37}$ and while it is true that the importance of circular causation processes should not be underrated, I firmly hold that the equilibrium, rather than cumulative causation view is the

${ }^{37}$ In a well-known 1953 book by Hamilton, cumulative causation and equilibrium are presented as antithetical principles (see Dugger 2003, pp. 65-66). 
correct interpretative approach to economic phenomena. ${ }^{38}$

As mentioned by Hodgson, critics of the idea that economic phenomena unroll like a natural selection process include J. R. Commons, who claims that such evolutionary processes as are observed in the economy are not natural, but artificially induced (see Commons 1924, pp. 376). There is no denying that a great many authors have correctly objected that Darwin and Spencer did not rule out a measure of intentionality in the selection process, but spelt out in bold letters that any intentions, where assumed, had to be explained (see Copeland 1931 and 1936, pp. 343-44 and Hodgson 2003, p. 91). Hence, Commons's criticism of Social Darwinism is certainly congruent enough. The underlying rationale is the belief that socioeconomic evolution and biological evolution are governed by altogether different mechanisms (Hodgson 2003, p. 86). ${ }^{39}$ Whereas evolution determines the success of the fittest in either case (and in economic selection processes the fittest are usually those who are found to be most efficient), economic events are generally conditioned by the power issue and organised forces can halt the progress of any firm, however efficient. ${ }^{40}$ In the above wording, this objection is not aimed at the distinctively Darwinian principle of the survival of the fittest, but at a particular version of Social Darwinism in which economic power is equated with efficiency and the most efficient economic organisations are assumed to prevail in the long run.

Be that as it may, there are solid reasons for arguing that economic selection mechanisms differ greatly from those governing natural

38 In fact, most institutionalists reject the neo-classical approach to equilibrium as unacceptable (see, for example, Miller 2002, p. 252 and 2003, p. 52, as well as Hamilton 2003, pp. 12-14).

${ }^{39}$ Marx, who was otherwise a great admirer of Darwin, denied the relevance of the Darwinian logic in areas such as history and politics.

${ }^{40}$ Authors critical of Social Darwinism include Bowles and Gintis. According to them, this argument misses the point since it fails to distinguish between economic-financial performance and efficiency. In competitive markets - they write (1986, p. 84) - survival is a function of profit, which should not be mistaken for efficiency. The distinction between profit and efficiency, they add, will be clearly recognized if we bear in mind that - assuming equal pay rates - profit is determined both by the output per labour unit generated in one hour of work and by the amount of work performed in one hour. And while it is true that the productivity level of the work performed is a good measure of efficiency, they conclude, the amount of work accomplished in a single hour is mainly an indicator of the employer's ability to put in place effective control procedures. Accordingly, if the workers of a cooperative should outperform their capitalistic competitors by streamlining production processes more effectively, they would attain higher efficiency levels even though they should resolve to work at a slower pace and put up with lesser profits. 
selection. ${ }^{41}$ In economic matters, to say that the fittest tend to prevail is just a tautology and, as such, will hardly add much to our understanding. Things would stand differently if it were possible to say, as social Darwinists mistakenly do, that the best economic performers are also the best organisations.

What, then, is the real bearing of Social Darwinism on a notion such as socialism?

The claim that workers are sure to acquire the right to self-manage their firms at some point in time is doubtless in line with the rationale behind Social Darwinism. Both Marx and Benedetto Croce were firmly persuaded that the long-term direction of history was one leading to ever greater freedom, while Social Darwinists, though holding that evolution proceeds in a given direction, reject any teleological approaches. Hence there is good ground for assuming that workers will in due time "get rid of the wage-yoke”, borrowing Giuseppe Mazzini’s words, and succeed in managing their firms on their own. The direction in which evolution is heading has as its starting point the sway of nature over man, the sway of capital over labour as an intermediate step and the liberation of man from the oppressive power of capital as its point of arrival. ${ }^{42}$ Inasmuch as it is true that history progresses in a precise direction, there can be little doubt that the economy will be heading towards self-management, a system in which alienation would be significantly lower compared to its level under capitalism (see Jossa 2012b). As mentioned in Finelli 2007 (p. 128), Marx looked upon capitalism as a reversed world where "alienation from labour and the impoverishment of the proletariat cannot exceed a certain level, at which the contradiction between the earning potential of the members of this class and the misery of their current circumstances will become so unbearable as to spark off the reversal of this reversal". 43

As far as Social Darwinism is concerned, the same cannot be said of centralised planning. Planning is hardly reconcilable with markets. The prerequisite for any attempt at reconciliation would be leaving with markets the most important choices - and this would be in stark contradiction with the very nature of planning. Accordingly, inasmuch as the rationale behind

\footnotetext{
${ }^{41}$ In Hayek' estimation, neither biological nor cultural evolution is governed by the laws of necessity, but cultural evolution, which is not genetically determined, generates diversity rather than uniformity (see Hayek 1982, pp. 35-37 and Leube 1988).

${ }^{42}$ Although Proudhon thought of property as the prerequisite for freedom, he objected to property when it was used as a tool for the exercise of man's dominion over man (see Solari 2012, p. 235).

${ }^{43}$ Evidence that democratic firm management is in the process of becoming a reality is provided by recent events in the United States, where companies establishing 'employee stock ownership plans' (ESOPs) and firms attributing part of the ownership interests in their capital resources to the workforce have been granted considerable tax cuts.
} 
planning is substituting centrally made choices for the choices made by individuals, there is no way of justifying it from the perspective of Social Darwinism. After all, it is difficult to see why individuals destined to attain ever more freedom should hand over their freedom of choice to a planning board which disregards the decisions made by the members of society.

\section{The selfish gene and socialism}

One way to contrast socialism with capitalism is to liken socialism to Christianity and to argue that while capitalism is grounded in egoism and characterised by "the dependence of individuals who are indifferent to one another", socialism is based on the need of individuals to entertain meaningful relationships with their fellow-beings (Marx 1857-58, p. 97). It is often argued that individuals are moved on by self-love and love for others, both of which are instincts that further the survival of the species, ${ }^{44}$ and capitalism is said to differ from socialism because the former is the outgrowth of self-love and the latter is mainly based on harmonious relationships with our fellow-beings. This view is shared by the very known Italian journalist and intellectual Eugenio Scalfari (1995, pp. 836-47), who holds that morals are but a reflection of the instinct for survival of the human species. ${ }^{45}$

However, as advocates of the above-mentioned gene selfishness assumption tend to reject this distinction, it is convenient to follow the line of reasoning of those modern biologists who contend that genes are selfish, that the behaviour of all living beings is principally governed by their genes and that the survival instinct is not inherent in the species. These propositions may justify the contention that, while capitalism is the product of gene selfishness, socialism is typified by a special attention for culture, in addition to instinct, which leads it to prioritise all such organisational forms as may result in a favourable terrain for feelings of solidarity (Rifkin 2009). ${ }^{46}$

\footnotetext{
${ }^{44}$ In the words of Adam Smith, "No matter how selfish you think man is, it is obvious that there are some principles in his nature that give him an interest in the welfare of others [...], pity and compassion” (see Smith 1759, pp. 203-04).

${ }^{45}$ In a well-known book, Singer (1980) provides an exhaustive analysis of the ethical foundations of Marx's theoretical approach and concludes that all Marx's propositions reflect the wish to get rid of a system in which individuals behave selfishly without the least regard to the needs of their fellow-beings.

${ }^{46}$ Commenting on Marx's critique of the individualistic view of man, Cornu argues that the materialistic conception of history evokes a novel form of society which realises the true essence of man and illustrates how man can humanise nature by adapting it to his needs and organising society in line with humane principles (Cornu 1948, p.186). In point of fact, this view is barely acceptable since it seems to descend from the Aristotelian and Rousseauistic assumption that man is by nature unselfish.
} 
The reader is likely to wonder what bearing these reflections have on the claim that socialism can be established by creating a self-managed firm system. The answer seems to be that modern producer cooperative theory (to which the socialism-worker control equation is linked - see, for example, Jossa 2012 and Jossa 2014) - starts out from the assumption that individuals are selfish and is, hence, a realistic approach, while a centrally planned system will never function effectively since it fails to leverage either the profit motive or cultural interests.

This point requires to be analysed in greater depth. The abovementioned claim that selfishness is a connotation of genes, rather than individuals, suggests stating the terms of the problem as follows: inasmuch as the gene selfishness theory is correct and Dawkins and Marx are right when they claim that unselfishness is a child of culture - specifically of interrelations established in the workplace, the system that may outperform competing systems is one which at once leverages selfishness and creates solidarity relationships between individual producers. A system with these specifics does exist and is a system of producer cooperatives, since it is this system that both leverages the personal profit motive by apportioning the firm's residual among the members and generates feelings of solidarity between them. At the other end of the spectrum is a centrally planned system, where the selfish drives of individuals are not heeded and where individual producers, far from being bound to each other by solidarity, fell hatred for the planning board which monitors their work inputs. On all accounts, to suggest that the generalised belief that work is being undertaken for the benefit of the community as a whole may breed adequate dedication to work and inter-worker solidarity is hardly realistic.

In other words, if culture is equated with the social environment and intellectual climate generated by a production mode, the argument that the culture of a centrally planned system with nationalised means of production breeds solidarity and commitment to production activities will barely hold. In Engels's words, "in communist society, where the interests of individuals are not opposed to one another, but, on the contrary, are united, competition is eliminated ... Private gain, the aim of the individual to enrich himself on his own, disappears" (Engels 1945, p. 566). But is this sure to happen? The Soviet-type planning model may help stifle the selfish drives that reign supreme in a capitalistic society, but if genes are selfish, what breeding ground would be available for nourishing germs capable of fostering solidarity feelings in the population? And what may induce individuals to

Neither is it acceptable to argue, as Cornu does, that by assigning Communism the mission to reinstate humane and collective values within society, Marx emphasised the dialectical nature of social development and vested in the proletariat the role of the antagonist expected to work towards progress (op cit, p. 155). 
produce despite their selfish genes?

Bearing in mind that revolutionary enthusiasm tends to be shortlived, it is difficult to argue that culture, i.e. the desire for interpersonal relationships that culture tends to breed, should justify centralised planning. It is worker control, not planning, that generates solidarity by its very nature and that satisfies the need to entertain harmonious interpersonal relationships. As is well known, in worker-run firms all the members are equally interested in the efficient management of their firm and decisions are made jointly, often following in-depth discussion and exchanges of opinions. And it is hard to think of anything capable of generating more solidarity than the joint discussion of the means that will best help achieve shared goals.

The idea that association is a means of emancipating workers was shared by John Stuart Mill. If workers are joined into cooperatives (where they become 'their own masters') - he wrote - the productiveness of labour tends to increase thanks to "the vast stimulus given to productive energies" by the awareness of the members that their increased work inputs will boost their incomes, but this material benefit - he added - "is as nothing compared with the moral revolution in society that would accompany it" thanks to the potential of cooperation for furthering "the transformation of human life, from a conflict of classes struggling for opposite interests, to a friendly rivalry in the pursuit of a good common to all, the elevation of the dignity of labour, a new sense of security and independence in the labouring class; and the conversion of each human being's daily occupation into a school of the social sympathies and the practical intelligence" (Mill 1871, p. 744). ${ }^{47}$ Elsewhere in the same book, Mill described cooperatives as "a course of education in those moral and active qualities by which alone success can be either deserved or attained” (Mill 1871, p. 716).

Marshall, too, was persuaded that cooperation "does rest in a great measure on ethical motives" and "has a special charm for those in whose tempers the social element is stronger” (see Marshall 1890, p. 292). The true co-operator, he wrote, "combines a keen business intellect with a spirit full of an earnest faith" and the cooperative movement "makes it its task to develop the spontaneous energies of individuals by educating them to collective action and teaching them to use collective resources for the attainment of shared goals." Although he did not deny affinities between cooperation and other movements, he emphasised that no other movement was as directly aimed to improve the quality of man himself (see Marshall

\footnotetext{
${ }^{47}$ As argued by Vanek (1971a, p 107), the fact that every week a man spends no fewer than forty of the most active hours of his life in a working environment where conflict is endemic must necessarily have an adverse impact on his whole life.
} 
1889, p. 227); and he put "the production of fine human beings" at the top of the list of the primary goals of this movement (see Marshall 1889, p. 228).

My line of reasoning so far may explain why I strongly disagree with all those Marxists who declare an interest in cooperation, but cling to the view that centralised planning (though not of the Soviet type) is a necessary constituent of socialism. Marx and Engels thought of socialism as a planned system because they were averse to markets and this aversion can quite naturally be traced to their Aristotelian view of man as a social animal. In two fine books, Cornu, who is one of the acutest commentators of Marx, tells us that Feuerbach and Hess thought of economic and social contradictions as generated by an ethical conflict between egoism and altruism (see Cornu 1948 and 1955). When Marx dealt with this conflict in the Introduction to the Critique of Hegel's Philsophy of Right (which dates from 1843) - Cornu argues - he translated it into a social conflict proper and by so doing he turned Communism into a doctrine of action, transferred the social problem to the ethical plain (as Feuerbach had done) and postulated its possible solution through altruism and love (Cornu 1948, pp. 154-55). Hence, there are reasons to argue that, as Marx had been thinking of individuals as social animals since his early youth, he tended to identify socialism which planning, which requires unselfish individuals, and not with a system of democratic firms which assumes, by its very nature, that individuals are selfish. On closer analysis, though, inasmuch as it is true that genes are selfish - as mentioned above - it is hardly possible to do without markets or to leave human instincts out of count.

Marx's view of human nature has already been discussed above. Here, it is interesting to note that both his firm choice of communism and his aversion to markets, which account for his advocacy of centralised planning, date back to 1943, his twenty-fifth year of age, and it is a wellknown fact that youthful decisions, especially if prompted by strong emotions, often remain pervasive influences throughout a man's life.

The same misconception is apparent in Gramsci, a supporter of the Bolshevik revolution who went to far as to argue that in a socialist society "the average proletarian psychology will quickly lose all the mythological, utopian, religious, petit-bourgeois ideologies: the communist psychology will quickly and permanently be consolidated, constantly roused by revolutionary enthusiasm" (Gramsci 1919-1920, p. 30). In addition to this, he wrote that "it is possible to imagine the coercive element of the State withering away by degrees, as ever more conspicuous elements of regulated society (ethical State or civil society) make their appearance" (Gramsci 
1975, vol. II, p. 764). ${ }^{48}$ On closer analysis, however, these reflections are not only unrelated to gene selfishness and where they should be brought to bear on issues associated with centralised planning they would have to be supported by evidence (which Gramsci did not provide) that a planned system would actually generate solidarity feelings. Not for nothing his claim was proved utterly wrong by the course of events in the countries organised in keeping with the system known as 'state socialism'.

\section{Conclusion}

The author's main proposition is that democratic firm management, one of the two ways to establish socialism, is more consistent with human nature, which is shaped by selfish genes. ! His second proposition is that democratic firm management can be implemented more easily than centralised planning since the retention of markets allows the selfish drives of human beings to act themselves out to the full. His third proposition is that democratic firm management is the type of socialist revolution that is more in keeping with Darwinian evolutionism.

\section{References:}

AA. VV., 1969, Marx vivo, Mondadori, Milan.

AA. VV., 1970, Marxismo ed etica, Ital. transl., Feltrinelli, Milan.

Althusser L., Balibar E., 1965, Leggere il Capitale, Ital. transl., Feltrinelli, Milan, 1968.

Althusser L., 1965a, Per Marx, Ital. transl., Editori Riuniti, Rome, 1969.

Althusser L., 1965b, L’oggetto del capitale, in Althusser \& Balibar 1965.

Althusser L., 1969 and 1995, Sur la reproduction, Presses universitaires de France, Paris.

Althusser L., 1972, Risposta a John Louis, in Althusser 2005.

Althusser L., 2005, I marxisti non parlano mai al vento, ed. by L. Tomasetta, Mimesis, Milan.

Ball T., Farr J., 1984, eds, After Marx, Cambridge University Press, Cambridge.

Bataille G., 1996, Il limite dell'utile, Ital. transl., Adelphi Edizioni, Milan, 2000.

\footnotetext{
${ }^{48}$ An additional interesting passage runs as follows: "Worker solidarity which in the union developed in the struggle against capitalism, in suffering and sacrifice, in the council is positive, is permanent, is made flesh even in the most negligible of moments of industrial production, is contained in the glorious consciousness of being an organic whole, a homogeneous and compact system which, by working usefully and disinterestedly producing social wealth, affirms its sovereignty and its power and freedom to create history" (Gramsci 1919-20, pp. 36-37; italics added).
} 
Bellofiore R., 2007, Da Marx a Marx?, manifestolibri, Rome.

Bernstein E., 1901, Zur Geschichte und Theorie des Sozialismus, Akademischer Verlag für Soziale Wissenschaft, Berlin.

Bloom S.F., 1943, Man of His Century: a Reconsideration of the Historical Significance of Karl Marx, in Wood 1988.

Bowles S., Gintis H., 1986, Democracy and Capitalism, Basic Books, New York.

Carver T., 1984, Marxism as Method, in Ball \& Farr 1984.

Commons J. R., 1924, Legal Foundations of Capitalism, University of Wisconsin Press, Milwaukee, 1968.

Copeland M. A., 1931, Economic Theory and the Natural Science Point of View, in American Economic Review, vol. 21, no. 1, March.

Copeland M. A., 1936, Common's Institutionalism in Relation to the Problem of Social Evolution and Economic Planning, in Quarterly Journal of Economics, vol. 50, no. 2, February.

Cornu A., 1948, Karl Marx e il pensiero moderno, Ital. transl., Turin, 1949.

Cornu A., 1955, Marx e Engels dal liberalismo al comunismo, Ital. transl., Milan, 1962.

Dawkins R., 1989, Il gene egoista, Ital. transl., Oscar Mondadori, Milan, 1995.

Di Siena G., 1972, Biologia, darwinismo sociale e marxismo, supplement to Critica marxista, no. 4, 1972.

Donnaruma C., Partyka N., 2012, Challenging the Presumption in Favor of Markets, in Review of Radical Political Economics, vol. 44, no.1.

Dugger W. M., 2003, David Hamilton: a Radical Institutionalist, in Journal of Economic Issues, vol. XXXVII, no. 1, March.

Engels F., 1845, Due discorsi a Eberfeld, in Marx \& Engels, Opere complete, vol. IV.

Finelli R., 2007, Un marxismo ‘senza Capitale’, in Bellofiore 2007.

Fromm E., 1961, Marx’s Concept of Man, Frederick Ungar, New York.

Fromm E., 1962, Marx e Freud, Ital. transl., Il Saggiatore, Milan, 1968.

Frowen S. F., 1997, ed., Hayek: Economist and Social Philosopher, MacMillan, London.

Gobetti P.,1924, La rivoluzione liberale, Einaudi, Turin, 1965.

Gramsci A., 1919-1920, L’Ordine nuovo, Einaudi, Turin, 1954.

Gramsci A., 1975, Quaderni del carcere, ed. by V. Gerratana, Einaudi, Turin.

Gustafsson Bo, 1974, Capitalismo e socialismo nel pensiero di Bernstein, in Istituto Giangiacomo Feltrinelli, 1974.

Hahn F.H., 1993, Il futuro del capitalismo: segni premonitori, in Rivista milanese di economia, no. 46, April-June. 
Hamilton D., 1999, Evolutionary Economics; a Study of Change in Economic Thought, Transaction Pubblishers, New Brunswick.

Hamilton D., 2003, Technology Is not Ancillary: the Dramatic and Prosaic in Economic Theory, in Journal of Economic Issues, vol. XXXVII, no. 1, March.

Haupt G., 1978, Marx e il marxismo, in Hobsbawm et alii 1978-82, vol. I.

Hayek F. A., 1982, Legge, legislazione e libertà, Ital. transl., Il Saggiatore, Milan, 1986.

Hobsbawm E. J., Haupt G., Marek F., Ragionieri E., Strada V., Vivanti C., 1978-1982, eds, Storia del marxismo, 5 vols, Einaudi, Turin.

Hodgson G.M., 2003, Darwinism and Institutional Economics, in Journal of Economic Issues, vol. 37, no. 1, March.

Istituto Giangiacomo Feltrinelli, 1974, Storia del marxismo contemporaneo, Feltrinelli, Milan.

Jossa B., 1998, Mercato, socialismo e autogestione, Carocci, Rome.

Jossa B., 2005, Marx, Marxism and the Cooperative Movement, in Cambridge Journal of Economics, no. 1.

Jossa B., 2010, Esiste un'alternativa al capitalismo?, manifestolibri, Rome.

Jossa B., 2011, A System of Self-managed Firms as a New Perspective on Marxism, Cambridge Journal of Economics, vol. 26, n. 4.

Jossa B., 2012, Cooperative Firms as a New Production Mode, in Review of Political Economy, vol. 24, n. 3.

Jossa B., 2013, Alienation and the Self-Managed Firm System, in Review of Radical Political Economics, vol. 46, no. 2, June.

Jossa B., 2014, A System of Cooperative Firms as a New Production Mode, Routledge, London.

Kant I., 1798, Se il genere umano sia in costante progresso verso il meglio, in Kant 1956.

Kant I., 1956, Scritti politici e di filosofia della storia e del diritto, UTET, Turin.

Karsz S., 1974, Teoria e politica: Louis Althusser, Ital. transl., Dedalo libri, Bari, 1976.

Keynes J. M., 1979, The Collected Writings of John Maynard Keynes, vol. XXIX; The General Theory and After: a Supplement, Macmillan, London.

Khalil E. L., Boulding K. E., 1996, eds, Evolution, Order and Complexity, Routledge, London.

Leube K. R., 1988, Social Policy: Hayek and Schmoller Compared, in International Journal of Social Economics, nos 9-10-11.

Lowit T., 1962, Marx et le 138ooperat 138ooperative, in Cahiers de l'institut de science èconomique appliquée, no. 129, September. 
Luporini C., 1966, Realtà e storicità: economia e dialettica nel marxismo, in Luporini 1974.

Luporini C., 1974, Dialettica e materialismo, Editori Riuniti, Rome.

Marcuse H., 1969, Un riesame del concetto di rivoluzione, in AA.VV. 1969.

Marcuse P., 2015, Cooperatives on the Path to Socialism?, in Monthly Review, vol. 66, no. 9.

Markus G., 1966, Marxismo e antropologia, Ital. transl, Liguori Editore, Naples, 1978.

Marshall A., 1889, Cooperation, in Marshall 1925.

Marshall A., 1890, Principles of Economics, Macmillan, London.

Marshall A., 1925, Memorials of Alfred Marshall, ed. by A. C. Pigou, Macmillan, London.

Marx K., Engels F., 1845-1846, L'ideologia tedesca, Ital. transl., 3rd edn, Editori Riuniti, Rome, 1969.

Marx K., Engels F., Opere complete, Editori Riuniti, Rome.

Marx K., 1844, Manoscritti economico-filosofici del 1844, Einaudi, Turin, 1968.

Marx K., 1845, Tesi su Feuerbach, in Marx \& Engels, Opere complete, vol. V.

Marx K., 1857-58, Lineamenti fondamentali della critica dell'economia politica, La Nuova Italia, Florence, 1970.

Marx K., 1859, Outline of the Critique of Political Economy, in Marx \& Engels, Collected Works, vol. 29.

Marx K., 1864, Inaugural Address of the Working Men's International Association, in Marx \&Engels, Collected Works, vol. 20.

Marx K., 1871, The Civil War in France, in Marx \& Engels, Collected Works, vol. 22.

Marx K., Engels F., 1975-2001, Collected Works, vols 1-49, Lawrence \& Wishart, London.

Mill J. S., 1871, Principi di economia politica, 3rd edn,, Ital. transl., UTET, Turin, 1953.

Miller E. S., 2002, Economics in a Public Interest: Remark upon Receiving the Veblen-Commons Award, in Journal of Economic Issues, vol. XXXVI, no. 2, June.

Miller E. S., 2003, Evolution and Stasis: the Institutional Economics of David Hamilton, in Journal of Economic Issues, vol. XXXVII, no. 1, March.

Mondolfo R., 1909, Feuerbach e Marx, in Mondolfo 1968.

Mondolfo R., 1962, La concezione dell'uomo in Marx, in Mondolfo 1968. 
Mondolfo R., 1968, Umanismo di Marx. Studi filosofici, 1908-1966, Einaudi.

Orfei R., 1970, Marxismo e umanismo, Coines Edizioni, Rome.

Piff, P., et al., 2012, Reply to Francis in Proceedings of the National Academy of Sciences, nos 109, 25.

Ratner C., 2013, Cooperation, Community, and Co-Ops in a Global Era, Springer Publishers.

Rawls J., 1971, A Theory of Justice, Harvard Economic Press, Cambridge Mass.

Rawls J., 2000, Lezioni di storia della filosofia morale, Ital. transl., Feltrinelli, Milan, 2004.

Rifkin J., 2009, Civiltà ed empatia, Ital. transl., Mondadori, Milan, 2011.

Scalfari E, 2012, La passione per l'etica, Mondadori, Milan.

Scalfari E., 1995, Alla ricerca della morale perduta, in Scalfari 2012.

Schaff A., Séve L., 1975, Marxismo e umanesimo, Dedalo libri, Bari.

Schaff A., 1971, Sulla traduzione francese della VI tesi di Marx su Feuerbach, Ital. transl., in Schaff \& Séve 1975.

Screpanti E., 2007, Democrazia radicale e lotta di classe: alcune precisazioni, in Il Ponte, LXIII, nos 8.

Sève L., 2004, Penser avec Marx aujourd'hui, vol. I, Marx et nous, La Dispute, Paris.

Singer P., 1980, Marx, Oxford University Press, London.

Smith A., 1759, Teoria dei sentimenti morali, Ital. transl., BUR, Milan, 2009.

Solari S., 2012, The 'Pratical Reason' of Reformers: Proudhon vs. Istitutionalism, in Journal of Economic Issues, vol. XLVI, no.1.

Streit M. E., 1997, Constitutional Ignorance, Spontaneous Order and RuleOrientation: Hayekian Paradigms from a Policy Perspective, in Frowen 1997.

Therborn G., 1971, Critica e rivoluzione; la Scuola di Francoforte, Ital. transl., Laterza, Bari, 1972.

Vanek J., 1971b, The Basic Theory of Financing of Participatory Firms, reprinted in Vanek 1977.

Vanek J., 1971c, The Participatory Economy: an Evolutionary Hypothesis on a Strategy for Development, Cornell University Press, Ithaca.

Vanek J., 1977, The Labor Managed Economy: Essays by J. Vanek, Cornell University Press, Ithaca.

Veblen T. B., 1964, What Veblen Thought, Augustus M. Kelley, New York. Vorländer C, 1911, Kant e Marx, in AA.VV. 1970.

Ward B. N., 1958, The Firm in Illyria; Market Syndicalism, in American 
Economic Review, vol. 48, no. 4, September.

Wood J. C., 1988, ed., Karl Marx's Economics: Critical Assessments, Croom Helm, New South Wales. 